\title{
Information systems research
}

УДК $510(022)$

doi: 10.20998/2522-9052.2020.1.12

В. Б. Кононов ${ }^{1}$, Л. М. Сакович ${ }^{2}$ Л. А. Коротченко ${ }^{3}$

${ }^{1}$ Харківський національний університет Повітряних Сил імені Івана Кожедуба, Харків, Україна

${ }^{2}$ Інститут спеціального зв'язку та захисту інформації Національного технічного університету

України “Київський політехнічний інститут" ім. І. Сікорського, Київ, Україна

${ }^{3}$ Військовий інститут телекомунікацій та інформатизації імені Героїв Крут, Київ, Україна

\section{МЕТОД ЗАВДАННЯ ПОСЛІДОВНОСТІ ПЕРЕВІРКИ РАДІОЕЛЕКТРОННИХ КОМПЛЕКСІВ ПРИ ТЕХНІЧНОМУ ОБСЛУГОВУВАННІ ЗА СТАНОМ}

\begin{abstract}
Анотація. В статті розглянуті особливості технічного обслуговування радіоелектронних комплексів великої розмірності (десятки і сотні тисяч елементів), що складаються з окремих підсистем, перевірку працездатності яких, технічне обслуговування та відновлення працездатності під час поточного ремонту можливо виконувати автономно. До таких об'єктів відносяться вузли і апаратні зв'язку, радіолокаційні станції, комплекси управління польотами та інші. В статті вперше запропоновано для підвищення ефективності технічного обслуговування за станом обгрунтовано встановлювати послідовність перевірки підсистем з комплексним врахуванням надійнісних, часових, вартісних показників. Крім того, запропоновано враховувати не тільки вартість засобів вимірювальної техніки, але і їх метрологічну надійність. Залежно від умов використання за призначенням комплексів означенні показники можуть мати різний вплив на ефективність технічної експлуатації, що запропоновано враховувати введенням коефіцієнтів, значення яких в кожному окремому випадку отримують в результаті обробки матеріалів експертного опитування провідних фахівців в цій галузі. Усі перераховані фактори об'єднуються комплексним показником, значення якого розраховують для кожної підсистеми комплексу. Для нормування значення комплексного показника вводиться імовірність переважного вибору підсистем комплексу. Потім в результаті ранжування підсистем за убиванням значення цієї імовірності визначають послідовність перевірки окремих підсистем комплексу. В такому випадку крім послідовності перевірки можливо визначити мінімальну кількість перевіряємих підсистем для забезпечення необхідного значення імовірності оцінки технічного стану виробу в цілому. В статті приведено блок-схему алгоритму реалізації методу, що дозволяє використовувати ЕОМ для автоматизації процесу. Приведений приклад використання методу і кількісна оцінка ефективності його застосування. Використання запропонованого методу приведе до впорядкування практичної реалізації технічного обслуговування за станом і підвищення його ефективності в реальних умовах експлуатації радіоелектронних комплексів великої розмірності.
\end{abstract}

Ключов і слов а: радіоелектронні комплекси; технічне обслуговування за станом; ймовірність переважного вибору.

\section{Вступ}

Постановка задачі. При технічному обслуговування радіоелектронних комплексів великої розмірності (десятки і сотні тисяч елементів), що складаються 3 окремих підсистем, необхідно виконувати перевірку їх працездатності. Під час поточного ремонту це можливо виконувати автономно, використовуючи стратегію реалізації (виконання тільки необхідного переліку робіт). Згідно з якою профілактичні роботи на об'єкті проводяться в строк та в обсязі, який встановлюється в результаті прийняття рішення за даними поточного контролю.

В ході реалізації цієї стратегії виникає проблема: в якій послідовності виконувати перевірки підсистем комплексу для визначення його реального стану 3 мінімальними працевитратами та при обмеженому часі, що дуже важливо в польових умовах та при веденні бойових дій, що й підкреслює актуальність цієї науково-практичної задачі.

Аналіз літератури. Фундаментальні теоретичні дослідження питань оптимізації виконання ТО наведені в [1], які в подальшому отримали розвиток в роботах $з$ підвищення експлуатаційної надійності виробів [2-4]. В [3] розглянуто особливості реалізації стратегії ТО за станом 3 контролем параметрів об'єкту або рівня його надійності. Також обгрунтовано критерії якості ТО. В [5] проведено аналіз осо- бливості ТО систем 3 часовою надлишковістю і запропоновані заходи щодо підвищення їх надійності. В сучасних роботах 3 технічної діагностики радіоелектронних систем для визначення послідовності перевірок, яка веде до скорочення часу локалізації дефекту, досить широко використовують ймовірність переважного вибору (ЙПВ) параметрів елемента $[6,7]$ :

$$
u_{i}=\lambda_{i} /\left(t_{i} \cdot \sum_{j=1}^{L} \lambda_{j} / t_{j}\right),
$$

де $\lambda_{i}$ - інтенсивність відмов елемента; $t_{i}$ - час виконання перевірки; $L$ - кількість елементів в об'єкті.

В [8] запропоновано для скорочення часу ТО виконувати перевірку параметрів виробу в порядку зменшення їх ЙПВ:

$$
u_{i}=T_{T O} \cdot C_{T O} \cdot v_{i} \cdot P_{i} /\left(t_{i} \cdot C_{i} \cdot q_{i}\right),
$$

де $T_{T O}, C_{T O}$ - тривалість та вартість ТО згідно інструкції; $v_{i}-$ значимість впливу параметру $i$ на працездатність виробу; $P_{i}$ - ймовірність того, що виріб працездатний, якщо параметр $i$ в нормі; $t_{i}, C_{i}-$ тривалість та вартість вимірювання значення параметра $i ; q_{i}$ - ймовірність помилки виконавця в оцінці значення параметра $i$. 
Крім того, досліджена залежність впливу метрологічної надійності засобів вимірювальної техніки (ЗВТ) на час виконання ТО об'єктів різноманітного призначення [9], яку в попередніх роботах щодо оптимізації часу виконання ТО не враховано.

3 проведеного аналізу слідує ,що в дійсний час найбільш доцільно використовувати ТО складних радіоелектронних комплексів (РЕК) за станом, при цьому необхідно комплексно враховувати надійнісні, часові і вартісні показники перевірки окремих підсистем, а також метрологічну надійність ЗВТ. Для цього необхідно запропонувати кількісний показник оцінки ЙПВ підсистем виробу з метою їх подальшого ранжування в порядку зменшення цього показника.

Мета статті: формалізація процесу визначення послідовності перевірок підсистем комплексу з врахуванням їх надійності, часових та вартісних показників для мінімізації часу і працевитрат на встановлення реального технічного стану об'єкту.

\section{Основний матеріал}

Технічне обслуговування (ТО) виробів - комплекс операції чи операція підтримання справності чи працездатності під час їх технічної експлуатації. ТО є складовою частиною експлуатації виробів та передбачає головним чином перевірку на відповідність параметрів технічним умовам. Під час експлуатації встановлюються види періодичного ТО: календарне, періодичне, комбіноване.

Календарне ТО проводиться у встановленні терміни з врахуванням умов експлуатації незалежно від напрацювання, при цьому легко планувати роботи але має місце необгрунтований розхід сил і засобів.

ТО за наробітком проводиться 3 урахування умов експлуатації після заданого наробітку виробу, при цьому має місце економія сил і засобів, але виникають труднощі при плануванні.

Комбіноване ТО містить у собі календарне (планування терміну виконання заздалегідь) і обслуговування за наробітком (виконання тільки необхідного переліку робіт). Стратегія його реалізації показана в літературі, нормативних і керівних документах ТО за станом [1-3].

Стратегія ТО за станом - це стратегія згідно 3 якою перелік та періодичність операцій ТО визначається фактичним технічним станом виробу в момент початку обслуговування. Вона грунтується на використані поточної інформації про дійсний стан об'єкта, яка отримується в процесі його експлуатації. При цій стратегії ТО всі види профілактичних робіт на об'єкті проводяться в строк та в обсязі, який встановлюється в результаті прийняття рішення за даними поточного контролю [3].

При організації експлуатації виробів за станом виникають такі завдання $[4,7]$ :

вибір мінімально необхідної кількості параметрів, що контролюються, 3 достатньою інформацією про стан системи в будь-який момент часу;

обгрунтування допустимих меж зміни параметрів , що контролюються;

розробка алгоритмів математичного забезпечення програм експлуатації виробів за станом;

створення технічних засобів контролю, діагностування, реєстрації і оперативної обробки інформації про стан параметрів виробу.

Розглядимо метод, що призначений для формування послідовності перевірки працездатності підсистем РЕК великої розмірності, які складаються 3 десятки і сотень тисяч електрорадіоелементів.

Сутність методу полягає в комплексному врахуванні показників надійності підсистем, вартості і часу перевірки їх працездатності, часу усунення несправності (або резервування підсистем), а також метрологічної надійності ЗВТ і вагових коефіцієнтів окремих показників, в цьому полягає наукова новизна і відмінність методу від відомих $[1-5,8]$.

Вихідні дані для реалізації методу отримують в результаті дослідної експлуатації РЕК.

Схема реалізації приведена на рис. 1, де також показаний математичний апарат, результат використання, обмеження і припущення.

РЕК складається із $M$ взаємопов'язаних підсистем (кластерів), при цьому допускається автономна перевірка їх працездатності. Для інструментальної перевірки значень параметрів використовується штатний комплект ЗВТ, який в совокупності дозволяє оцінити працездатність всіх підсистем комплексу.

Послідовність перевірки підсистем повинна бути такою, що в першу чергу необхідно перевіряти найменш надійні підсистеми, які потребують мінімальних працевитрат на вимірювання параметрів i усунення несправностей (при наявності запасних

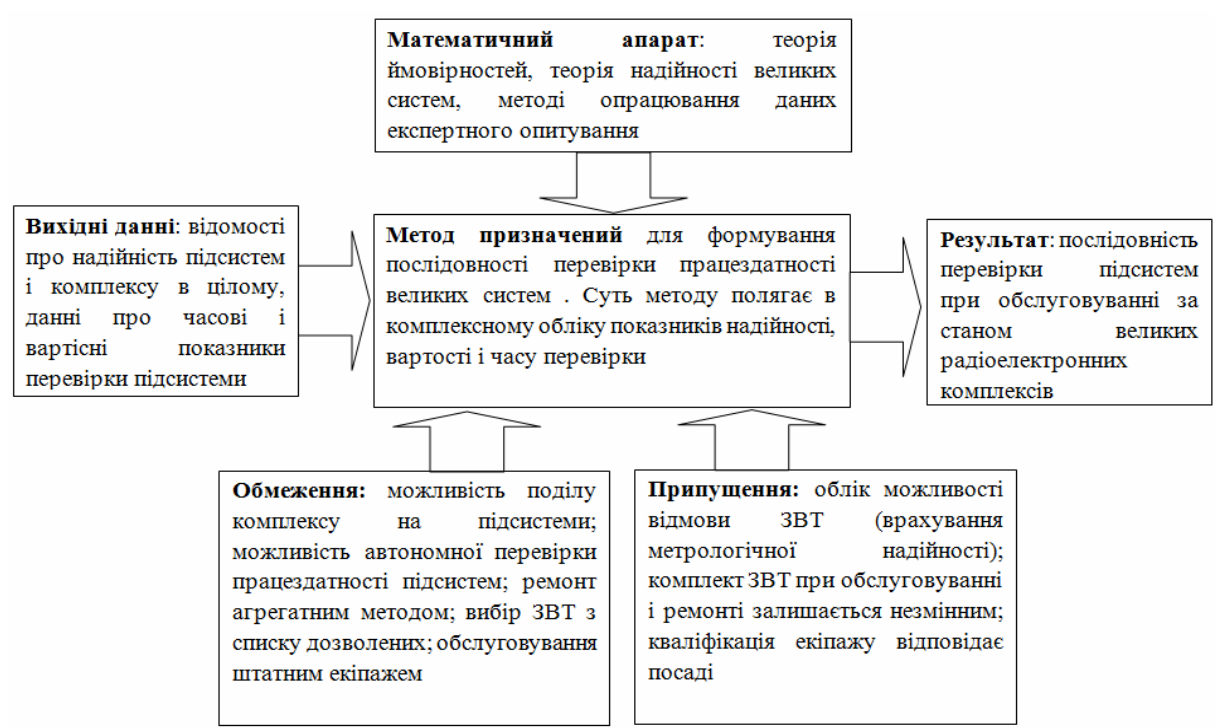

Рис. 1. Схема реалізації метода ранжування підсистем комплексу для перевірки працездатності з врахуванням надійності, часових та вартісних факторів 
агрегатів можлива організація ремонту агрегатним методом) 3 мінімальною вартістю використовуємих ЗВТ і максимально можливим значенням їх метрологічної надійності. Крім того, в залежності від умов експлуатації і вимог користувачів послуг РЕК вводяться коефіцієнти, які враховують важливість складових комплексного показника кожної підсистеми. Результати обробки даних експертних опитувань фахівців в галузі технічної експлуатації складних систем показали, що найбільшу вагу має середній час усунення несправностей $(k=0,4)$, потім надійність підсистеми $(a=0,3)$, вартість ЗВТ $(d=0,2)$, трудоємність перевірки $(b=0,1)$. Значення вагових коефіцієнтів розраховані за відомими методиками [10-12]. Надійність кожної підсистеми РЕК розраховують як

$$
p_{i}=a z_{i} / \sum_{j=1}^{L} z_{j}=a z_{i} \cdot T
$$

де $z_{i}$ - параметр потоку відмов підсистеми $i ; T$ напрацювання РЕК на відмову.

Якщо підсистеми РЕК виконанні на однотипній елементній базі, то можливо використовувати вираз

$$
p_{i}=a \cdot L_{i} / L ; \quad l=\sum_{i=1}^{M} L_{i}
$$

де $L_{i}$ - кількість електрорадіоелементів підсистеми $i$, а $L-$ їх загальна кількість в РЕК.

В такому випадку $p_{i} / a$ - ймовірність відмови підсистеми $i$ при відмові РЕК, тоді

$$
(1 / a) \cdot \sum_{i=1}^{M} p_{i}=1
$$

Відносна трудоємність (час) перевірок стану підсистем дорівнює

$$
\tau_{i}=v \cdot t_{i} / \sum_{j=1}^{M} t_{j} ; \quad(1 / v) \cdot \sum_{i=1}^{M} \tau_{i} .
$$

Відносна вартість ЗВТ для перевірки параметрів підсистеми $i$ дорівнює

$$
S_{i}=d \cdot C_{i} / \sum_{j=1}^{M} C_{j} ; \quad(1 / d) \cdot \sum_{i=1}^{M} S_{i}=1,
$$

де $C_{i}$ - вартість ЗВТ для перевірки працездатності підсистеми $i$. Відносний час відновлення (заміни або резервування) підсистеми $i$

$$
f_{i}=k \cdot t_{v i} / \sum_{j=1}^{M} t_{v j} ; \quad(1 / k) \cdot \sum_{i=1}^{M} f_{i} ;
$$

де $t_{v i}$ - час відновлення підсистеми $i$.

Для визначення послідовності перевірки підсистем РЕК при його ТО за станом пропонується для кожної підсистеми оцінити значення комплексного показника, що враховує всі розглянуті складові

$$
u_{i}=p_{i} \cdot P_{s i} /\left(\tau_{i} \cdot S_{i} \cdot f_{i}\right) ; \quad P_{s i}=\prod_{j=1}^{m_{i}} P_{M j},
$$

де $P_{s i}-$ метрологічна надійність ЗВТ для перевірки підсистеми $i ; m_{i}$ - кількість ЗВТ для перевірки підсистеми $i ; P_{M j}$ - метрологічна надійність окремих ЗВТ для перевірки підсистеми $i$. Значення $u_{i}-$ безрозмірне і сильно відрізняється для різноманітних підсистем РЕК. Тому для ранжування підсистем доцільно використовувати їх ЙПВ перевірки

$$
U_{i}=u_{i} /\left(\sum_{j=1}^{M} u_{j}\right) ; \quad \sum_{i=1}^{M} U_{i}
$$

Підсистеми РЕК перевіряють в послідовності убування значень $U_{i}$. При заданому значенні імовірності визначення технічного стану РЕК $P_{D}$ підсистеми перевіряються згідно встановленого рангу до виконання умови

$$
\sum_{i=1}^{n} u_{i} / \sum_{i=1}^{M} u_{i} \geq P_{D} ; \quad 1 \leq n \leq M
$$

де $n$ - кількість перевірених підсистем РЕК при ТО за станом. В такому випадку необхідний мінімальний час для перевірки РЕК

$$
T_{n}=\sum_{i=1}^{n} t_{i}
$$

а виграш у відносному часі в порівнянні 3 повною перевіркою підсистем РЕК складе

$$
\eta=\left(\left(\sum_{i=1}^{M} t_{i}-T_{n}\right) / \sum_{i=1}^{M} t_{i}\right) \cdot 100 \%
$$

Схема реалізації запропонованого методу ранжування підсистем РЕК при ТО за станом приведена на рис. 2.

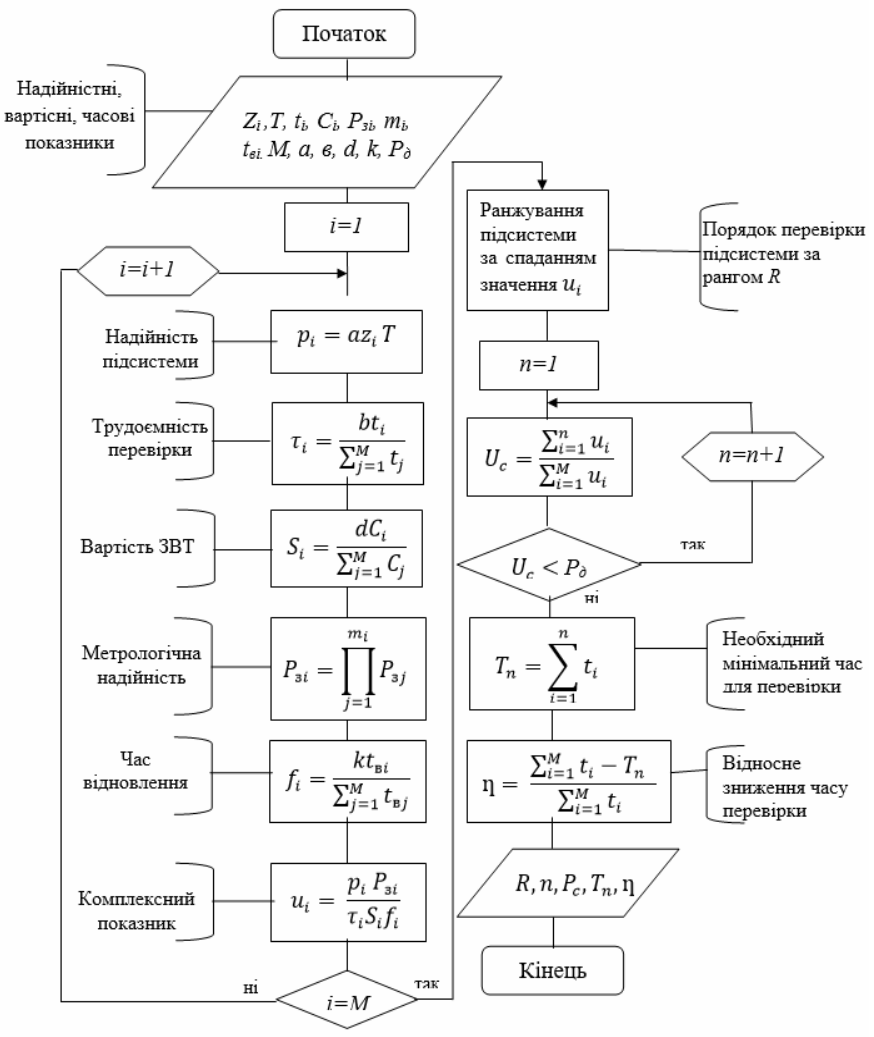

Рис. 2. Схема реалізації метода ранжування підсистем комплексу при обслуговуванні за станом

Розглянемо порядок використання методу на прикладі комплексу, приведеного в табл. 1, де показані вихідні дані і результати проміжних обчислень.

РЕК складається із $M=11$ підсистем, $r_{i}-$ ранг підсистеми (порядковий номер перевірки). Наробіток на відмову РЕК Т=10000 год., параметр потоку відмов

$$
z=1 \cdot 10^{-4} \text { год }^{-1} \text {. }
$$


Таблиия 1 - Приклад ранжування підсистеми комплексу для обслуговування за станом

\begin{tabular}{|c|c|c|c|c|c|c|c|c|c|c|c|}
\hline$i$ & $Z_{i}$ & $T_{i}$ & $C_{i}$ & $t_{\sigma i}$ & $\boldsymbol{P}_{3 i}$ & $p_{i}$ & $\tau_{i}$ & $S_{i}$ & $f_{i}$ & $u_{i}$ & $r_{i}$ \\
\hline 1 & $4 \cdot 10^{-6} 20 \partial^{-1}$ & $15 \mathrm{xB}$ & 2500 грн & $10 \mathrm{xB}$ & 0,85 & 0,012 & 0,00811 & 0,02463 & 0,0221 & 1229,153 & 9 \\
\hline 2 & $4 \cdot 10^{-6} 20 \partial^{-1}$ & $15 \mathrm{xB}$ & 2000 грн & $12 \mathrm{xB}$ & 0,88 & 0,012 & 0,00811 & 0,0197 & 0,02652 & 2492,317 & 8 \\
\hline 3 & $10 \cdot 10^{-6} 20 \partial^{-1}$ & $20 \mathrm{xB}$ & 1000 грн & $15 \mathrm{xB}$ & 0,81 & 0,03 & 0,00108 & 0,00985 & 0,03315 & 68906,904 & 1 \\
\hline 4 & $10 \cdot 10^{-6} \mathrm{rod}^{-1}$ & $20 \mathrm{xB}$ & 1200 грн & $20 \mathrm{xB}$ & 0,79 & 0,03 & 0,00108 & 0,01182 & 0,0442 & 41992,7783 & 2 \\
\hline 5 & $6 \cdot 10^{-6} 20 \partial^{-1}$ & $10 \mathrm{xB}$ & 1800 грн & $11 \mathrm{xB}$ & 0,91 & 0,018 & 0,0054 & 0,01773 & 0,0243 & 7038,938 & 6 \\
\hline 6 & $7 \cdot 10^{-6} 20 \partial^{-1}$ & $10 \mathrm{xB}$ & 2100 грн & $8 \mathrm{xB}$ & 0,88 & 0,021 & 0,0054 & 0,02069 & 0,0177 & 9336,25 & 4 \\
\hline 7 & $6 \cdot 10^{-6} 20 \partial^{-1}$ & $10 \mathrm{xB}$ & 1200 грн & $16 \mathrm{xB}$ & 0,93 & 0,018 & 0,0054 & 0,01182 & 0,0353 & 7410,793 & 5 \\
\hline 8 & $25 \cdot 10^{-6} 20 \partial^{-1}$ & $30 \mathrm{xB}$ & 1500 грн & $25 \mathrm{xB}$ & 0,95 & 0,075 & 0,01621 & 0,01477 & 0,05525 & 5386,28 & 7 \\
\hline 9 & $4 \cdot 10^{-6} 20 \partial^{-1}$ & $15 \mathrm{xB}$ & 3500 грн & $22 \mathrm{xB}$ & 0,89 & 0,012 & 0,00810 & 0,03448 & 0,04862 & 785,65 & 11 \\
\hline 10 & $4 \cdot 10^{-6} 20 \partial^{-1}$ & $15 \mathrm{xB}$ & 3000 грн & $18 \mathrm{xB}$ & 0,87 & 0,012 & 0,00810 & 0,02955 & 0,03978 & 1095,11 & 10 \\
\hline 11 & $20 \cdot 10^{-6} 20 \partial^{-1}$ & $25 \mathrm{xB}$ & 500 грн & $24 \mathrm{XB}$ & 0,88 & 0,06 & 0,01351 & 0,00492 & 0,05304 & 14954,924 & 3 \\
\hline
\end{tabular}

Сумарний час перевірки всіх підсистем

$$
\sum_{i=1}^{11} t_{i}=20300 \mathrm{xв}
$$

загальна вартість використаних ЗВТ

$$
\sum_{i=1}^{11} c_{i}=20300 \text { грн ; }
$$

загальний час відновлення при відмові всіх підсистем

$$
\sum_{i=1}^{11} t_{v i}
$$

Результати розрахунку ЙПВ підсистем РЕК наведенні в табл. 2.

Таблиия 2 - Оцінка ймовірності пріоритетного вибору $\mathbf{i}$ порядку (рангу) перевірки підсистем комплексу

\begin{tabular}{|c|c|c|c|}
\hline $\begin{array}{c}\text { Номер } \\
\text { підсисте- } \\
\text { ми }\end{array}$ & $\begin{array}{c}\text { Комплекс- } \\
\text { ний показ- } \\
\text { ник }\end{array}$ & $\begin{array}{c}\text { Ймовірність } \\
\text { пріоритетно- } \\
\text { го вибору }\end{array}$ & $\begin{array}{c}\text { Ранг } \\
\text { підсис- } \\
\text { теми }\end{array}$ \\
\hline 1 & 1229 & 0,00765 & 9 \\
\hline 2 & 2492 & 0,01551 & 8 \\
\hline 3 & 68907 & 0,42899 & 1 \\
\hline 4 & 41993 & 0,26144 & 2 \\
\hline 5 & 7039 & 0,04401 & 6 \\
\hline 6 & 9336 & 0,05812 & 4 \\
\hline 7 & 7411 & 0,04614 & 5 \\
\hline 8 & 5386 & 0,03350 & 7 \\
\hline 9 & 786 & 0,004899 & 11 \\
\hline 10 & 1095 & 0,00682 & 10 \\
\hline 11 & 14955 & 0,093106 & 3 \\
\hline
\end{tabular}

На рис. 3 показана ймовірність оцінки технічного стану РЕК при перевірці підсистем за порядковими номерами (1) і після їх ранжування (2). При заданій ймовірності $P_{D}=0,9$. Отримуємо, що в першому випадку необхідно перевірити 9 підсистем, а в другому всього 6, тобто виграш складає $33 \%$.

Так як в першу чергу перевіряються найменш надійні підсистеми РЕК то зрозуміло, що ймовірність безвідмовної роботи (рис. 4) і напрацювання на відмову (рис. 5) перевірених підсистем буде менше, ніж при перевірці за їх номерами.

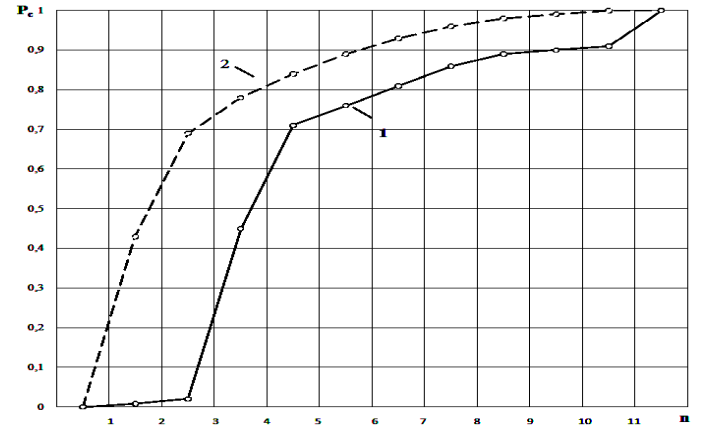

Рис. 3. Ймовірність оцінки технічного стану РЕК при перевірці підсистем за порядковими номерами (1) і після їх ранжування (2)

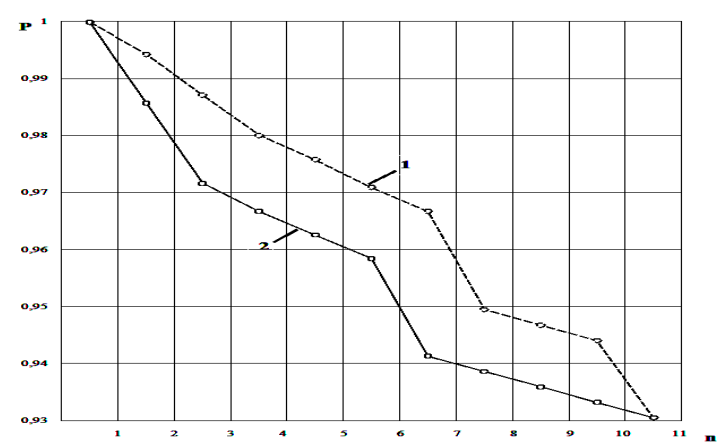

Рис. 4. Оцінка надійності перевіряємого числа підсистем за місяць роботи

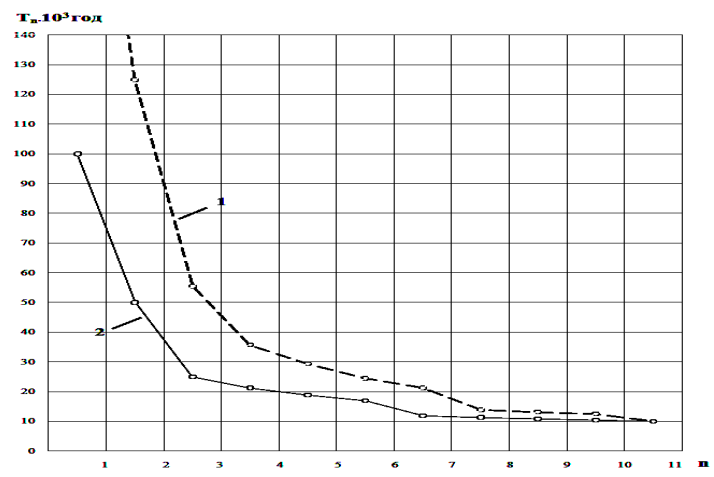

Рис. 5. Напрацювання на відмову за місяць перевірених підсистем 
Наприклад, при заданій ймовірності безвідмовної робота за місяць ( $t=720$ год.)

$$
P=\exp \left(-t \cdot \sum_{i=1}^{n} Z_{i}\right) ; \quad 1 \leq n \leq M
$$

рівною 0,95 отримуємо, що при реалізації запропонованого методу достатньо перевірити 6 підсистем, а при перевірці за номерами необхідна перевірка 7 підсистем, тобто виграш - 14\%.

Якщо задати напрацювання перевірених підсистем $\mathrm{T}=20000$ год, то використовуючи запропонований метод досить перевірити 5 підсистем, а за номерами 7. Виграш за рахунок скорочення числа перевірених підсистем - 28\%.

\section{Висновки}

1. В статті вперше запропоновано метод, якій заснований на комплексному використанні надійнісних, часових і вартісних показників при оцінці ймовірності переважного вибору для перевірки за станом.
2. На відміну від відомих методів також враховується метрологічна надійність засобів вимірювальної техніки і результати експертного опитування фахівців по визначенню вагових коефіцієнтів складових комплексного показника при ранжуванні підсистем перевіряємого виробу. Також відрізняється від відомих доступністю вихідних даних.

3. Реалізація методу формалізована у вигляді схеми яку можливо використовувати для розробки програмного забезпечення ЕОМ.

4. Приведений приклад практичного використання методу і показано, що ефект від його використання складає від 14\% до 33\% в залежності від показників, які оцінюються.

5. Подальші дослідження доцільно направити на розгляд можливості використання запропонованої ймовірності переважного вибору для розробки оптимальних алгоритмів діагностування РЕК із структурно пов’язаними підсистемами.

\section{СПИСОК ЛІТЕРАТУРИ}

1. Барзилович Е. Ю. Модели технического обслуживания сложных систем. Москва. Высшая школа, 1982. 231 с.

2. Острейковский В. А. Теория надежности. Москва. Высшая школа, 2003. 463 с.

3. Василишин В. І., Женжера С. В., Чечуй С. В., Глушко А. П. Основи теорії надійності та експлуатації радіоелектронних систем. Харків : ХНУПС, 2018. 268 с.

4. Половко А. М., Гуров С. В. Основы теории надежности. Санкт-Петербург :БХВ-Петербург, 2006. 704 с.

5. Креденцер Б. П. Техническое обслуживание и надежность системы с временным резервированием: монография. Киев : Феникс, 2016. 384 с.

6. Ксенз С. П. Борьба с диагностическими ошибками при техническом обслуживании и ремонте систем управления связи и навигации. Санкт-Петербург : ВАС, 2006. 240 с.

7. Ryzhov Ye. V, Sacovych L. N, Vankevych Petro. Optimization of requirements for measuring at metrological service of communication tools. Measurement, Journal of International Measurement Confederation. 2018. Vol. 123. P. 19-25. DOI: https//doi.org/10.1016/j. measurement.2018.03.055.

8. Сакович Л. Н., Бобро Р. А. Выбор параметров и последовательности их измерения при техническом обслуживании средств связи по состоянию. Зв язок. 2006. № 3. С. 54-56.

9. Сакович Л. М., Криховецький Г. Я., Небесна Я. Е. Оцінка впливу метрологічної надійності засобів вимірювань на час виконання технічного обслуговування засобів спеціального зв'язку. Системи управління, навігації та зв'язку. 2018. Вип. 2 (48). C.164-166. DOI: https://doi.org.10.26906/SUNZ.2018.2.164.

10. Орлов А. И. Экспертные оценки. Москва. Наука, 2002. 150 с.

11. Коваленко И. И., Драган С. В., Рыхальский М. А. Экспертные оценки в управлении информационными проектами. Николаев. НУК, 2007. 168 с.

12. Шмерлин Д. С., Дубровский С. А. Экспертные оценки: методы и применения. Москва. ЭКСПО, 2001. 228 с.

\section{REFERENCES}

1. Barzilovich, E.Y. (1982), Maintenance models for complex systems, High School, Moscow, 231 p.

2. Ostreykovsky, V.A. (2003), Reliability theory, Higher School, Moscow, 463 p.

3. Vasilishin, V.I., Zhenzhera, S.V., Chechui, S.V. and Glushko, A.P. (2018), Fundamentals of the theory of reliability and operation of radioelectronic systems, KhNUPS, Kharkiv, 268 p.

4. Polovko, A.M. and Gurov, S.V. (2006), Fundamentals of reliability theory, BHC-Petersburg, St. Petersburg, 704 p.

5. Kredentzer, B. P. (2016), Maintenance and reliability of the system with temporary redundancy, Phoenix, Kiev, $384 \mathrm{p}$.

6. Ksenz, S.P. (2006), Combat diagnostic errors in the maintenance and repair of communication and navigation control systems, YOU, St. Petersburg, $240 \mathrm{p}$.

7. Ryzhov, Ye.V., Sacovych, L.N. and Vankevych, Petro (2018), "Optimization of requirements for measuring at metrological service of communication tools", Measurement, Journal of International Measurement Confederation. Vol. 123, pp. 19-25, DOI: https//doi.org/10.1016/j. measurement.2018.03.055.

8. Sakovich, L.M. and Bobro, R.A. (2006), "Choice of parameters and sequence of their measurement during maintenance of communication means by state", Communication, No. 3, pp. 54-56.

9. Sakovich, L.M, Krykhovetsky, G.Y. and Heavenly, Y.E. (2018), "Assessment of the impact of metrological reliability of the measuring instruments on the time of maintenance of the special communication facilities", Management, navigation and communication systems, No. 2 (48), pp. 164-166, DOI: https: //doi.org.10.26906/SUNZ.2018.2.164.

10. Orlov, A.I. (2002), Expert assessments, Science, Moscow, 150 p.

11. Kovalenko II., Dragan, S.V. and Ryhalsky, M.A. (2007), Expert assessments in information project management, NUS, 168 p.

12. Shmerlin, D.S. and Dubrovsky, S.A. (2001), Expert assessments: methods and applications, EXPO, Moscow, 228 p. 
ВідОМОсті ПРО АВТОРів / АвOUT тHE AUTHORS

Кононов Володимир Борисович - доктор технічних наук професор, начальник кафедри метрології та стандартизації, Харківський національний університет Повітряних Сил імені Івана Кожедуба, Харків, Україна;

Vladimir Kononov - Doctor of Technical Science, Professor, Chief of the Department of metrology and standardization, Ivan Kozhedub Kharkiv National Air Force University, Kharkiv, Ukraine; e-mail: aveprofessor@gmail.com; ORCID ID: http://orcid.org/0000-0002-9946-5056.

Сакович Лев Миколайович - кандидат технічних наук, доцент, доцент кафедри, Інститут спеціального зв'язку та захисту інформації Національного технічного університету України "КП імені Ігоря Сікорського", Київ, Україна;

Lev Sakovych - candidate of Technical Science, associate professor, associate professor of the Department of Institute of special communication and information security of National Technical University of Ukraine "KPI", Kyiv, Ukraine; e-mail: lev@sakovich.com.ua; ORCID ID: http://orcid.org/0000-0002-8257-7086.

Коротченко Людмила Анатоліївна - ад'юнктка, Військового інституту телекомунікацій та інформатизації імені Героїв Крут. Київ, Україна;

Liudmyla Korotchenko - Graduated, a Heroic Kryt Military Institute of telecommunication, Kyiv, Ukraine; e-mail: lev@sakovich.com.ua; ORCID ID: http://orcid.org/0000-0002-8257-7086.

\section{Метод задания последовательности проверки радиоэлектронных комплексов при техническом обслуживании по состоянию}

В. Б. Кононов, Л. М. Сакович, Л. А. Коротченко

Аннотация. В статье рассмотрены особенности технического обслуживания радиоэлектронных комплексов большой размерности (десятки и сотни тысяч элементов), состоящие из отдельных подсистем, проверку работоспособности которых, техническое обслуживание и восстановление работоспособности во время текущего ремонта возможно выполнять автономно. К таким объектам относятся узлы и аппаратные связи, радиолокационные станции, комплексы управления полетами и другие. В статье впервые предложено для повышения эффективности технического обслуживания по состоянию устанавливать последовательность проверки подсистем с комплексным учетом надежностных, временных и стоимостных показателей. Кроме того, предложено учитывать не только стоимость средств измерительной техники, но и их метрологическую надежность. В зависимости от условий использования по назначению комплексов указанные показатели могут иметь различное влияние на эффективность технической эксплуатации, что предложено учитывать введением коэффициентов, значение которых в каждом конкретном случае получают в результате обработки материалов экспертного опроса ведущих специалистов в этой области. Все перечисленные факторы объединяются комплексным показателем, значение которого рассчитывают для каждой подсистемы комплекса. Для нормирования значение комплексного показателя вводится вероятность предпочтительного выбора подсистем комплекса. Затем в результате ранжирования подсистем по уменьшению значения этой вероятности определяют последовательность проверки отдельных подсистем комплекса. В такие случаи креме последовательности проверки возможно определить минимальное количество проверяемых подсистем для обеспечения необходимого значения вероятности оценки технического состояния изделия в целом. В статье приведена блок-схема алгоритма реализации метода, позволяющая использовать ЭВМ для автоматизации процесса. Приведен пример использования метода и количественная оценка эффективности его применения. Использование предложенного метода приведет до упорядочения практической реализации технического обслуживания по состоянию и повышения его эффективности в реальных условиях эксплуатации радиоэлектронных комплексов большой размерности.

Ключевые сл ов а : радиоэлектронные комплексы; техническое обслуживание по состоянию; вероятность предпочтительного выбора.

\section{The method of specifying the sequence of radio-electronic complexes verification during maintenance as of state \\ V. Kononov, L. Sakovych, L. Korotchenko}

Abstract. The article considers the features of maintenance of large-scale radio-electronic complexes (tens and hundreds of thousands of elements), consisting of separate subsystems, the verification of which can be performed autonomously during maintenance and restoration during the current repair. These facilities include nodes and communications, radars, flight management systems and more. For the first time, the article proposes to establish the sequence of subsystem verification with a comprehensive consideration of reliable, time, and cost indicators to improve the efficiency of maintenance. In addition, it is proposed to take into account not only the cost of measuring equipment, but also their metrological reliability. Depending on the conditions of use for the purpose of the complexes, the determined indicators may have different effects on the efficiency of technical operation, which is offered to take into account the introduction of coefficients, whose values are obtained in each case as a result of processing expert examination materials of leading experts in this field. All these factors are combined by a complex indicator, the values of which are calculated for each subsystem of the complex. To normalize the value of a complex indicator, the probability of preference for subsystems of the complex is introduced. Then, as a result of ranking subsystems by killing, the values of this probability determine the sequence of verification of individual subsystems of the complex. In this case, in addition to the verification sequence, it is possible to determine the minimum number of subsystems to be tested to provide the necessary probability of estimating the technical condition of the product as a whole. The block diagram of the algorithm of the method realization that allows to use the computer for process automation is presented in the article. An example of using the method and quantifying the effectiveness of its application are given. The use of the proposed method will streamline the practical implementation of maintenance on the condition and increase its efficiency in real conditions of operation of large-scale radioelectronic complexes.

Keywords : radioelectronic complexes, state of the art maintenance; likelihood of preference. 